\title{
Supplementation of lamb ewes with different protein sources in deferred marandu palisadegrass (Brachiaria brizantha cv. marandu) pasture
}

[Suplementação de matrizes ovinas com diferentes fontes de proteína em pasto diferido de capim-marandu (Brachiaria brizantha $c v$. Marandu)]

A.L.C. Gurgel ${ }^{1}$, G.S. Difante ${ }^{1}$, J.V. Emerenciano Neto ${ }^{2}$, M.G. Costa ${ }^{3}$, J.L.S. Dantas ${ }^{4}$, L.C.V. İtavo ${ }^{1}$, C.C.B.F. Itavo ${ }^{1}$, M.G. Pereira ${ }^{1}$, J.G. Rodrigues ${ }^{1}$, I.L.S. Oliveira ${ }^{3}$, J.I.G. Bezerra ${ }^{3}$

${ }^{1}$ Universidade Federal de Mato Grosso do Sul - Campo Grande, MS

${ }^{2}$ Universidade Federal do Vale do São Francisco - Petrolina, PE

${ }^{3}$ Universidade Federal do Rio Grande do Norte - Macaíba, RN ${ }^{4}$ Universidade Federal da Paraíba - Areia, PB

\begin{abstract} h.L.S. Oliveira https://orcid.org/0000-0003-3685-289X) J.I.G. Bezerra

https://orcid.org/0000-0002-1493-0263
\end{abstract}

A.L.C. Gurgel

https://orcid.org/0000-0001-5911-369X G.S. Difante

https://orcid.org/0000-0001-6610-8952 .V. Emerenciano Neto M.G. Costa

https://orcid.org/0000-0003-0525-033 J.L.S. Dantas https://orcid.org/0000-0003-2527-552 L.C.V. İtavo

https://orcid.org/0000-0001-6895-8483 C.C.B.F. İtavo

https://orcid.org/0000-0002-4790-8177 M.G. Pereira https://orcid.org/0000-0002-1117-890X
J.G. Rodrigues

The objective of this study was to evaluate the effect of different protein sources on the performance of lamb ewes and their offspring supplemented in deferred pasture. The treatments were the different protein sources: soybean meal, cotton cake, babassu cake and coconut cake. The ewes were weighed and evaluated for their body condition score during the gestation, parturition and weaning phases. The lambs were weighed at birth and at weaning. The structural variables and chemical composition of the pasture were evaluated during the usage period. Grass height and forage mass were higher when the ewes were in the gestation and weaning stages. The leaf mass was not altered during the pasture usage with a mean value of $566.1 \mathrm{~kg} \mathrm{ha}{ }^{-1} \mathrm{DM}$. The highest levels of crude protein in the leaf blade were observed during the parturition and weaning phases. The body weight of the ewes did not differ between the sources with averages 45.0, 39.9 and $36.6 \mathrm{~kg}$ for the gestation, parturition and weaning phases, respectively. Weights at birth and at weaning had an effect from protein sources, with the highest values observed in the lambs of ewes who received soybean meal and babassu cake supplementation. The lambs of ewes supplemented with soybean had higher average daily gain and total gain. Babassu, coconut and cotton cakes can replace soybean meal in supplementation of ewes in deferred pasture.

Keywords: alternative supplementation, animal production, lambs, pasture, sheep breeding

\section{RESUMO}

O objetivo deste estudo foi avaliar o efeito de diferentes fontes de proteína no desempenho de ovelhas e suas crias suplementadas em pastagem diferida. Os tratamentos foram as diferentes fontes proteicas: farelo de soja, tortas de algodão, babaçu e coco. As ovelhas foram pesadas e avaliadas quanto ao escore de condição corporal durante as fases de gestação, parição e desmame. Os cordeiros foram pesados no nascimento e no desmame. As variáveis estruturais e a composição química do pasto foram avaliadas durante o período de uso. A altura do dossel e a massa de forragem foram maiores quando as ovelhas estavam nas fases de gestação e desmame. A massa foliar não foi alterada durante o uso do pasto, com um valor médio de 566, $1 \mathrm{~kg} \mathrm{ha-}{ }^{1} \mathrm{MS}$. Os maiores teores de proteína bruta na lâmina foliar foram observados durante as fases de parto e desmame. O peso corporal das ovelhas não diferiu entre as fontes proteicas, com médias de 45,0, 39,9 e 36,6kg para as fases de gestação, parto e desmame, respectivamente. Os pesos a nascimento e ao desmame tiveram efeito das fontes proteicas, com os maiores valores observados nos cordeiros de ovelhas que receberam suplementação com farelo de soja e torta de babaçu. Os cordeiros suplementados com soja apresentaram maior ganho médio diário e ganho total. As tortas de babaçu, coco e algodão podem substituir o farelo de soja na suplementação de ovelhas em pastagem diferida.

Palavras-chave: suplementação alternativa, produção animal, ovinos, pasto, ovinocultura

Recebido em 19 de setembro de 2019

Aceito em 11 de março de 2020

E-mail: antonioleandro09@gmail.com 


\section{INTRODUCTION}

Pasture deferment consists in selecting a pasture area of the property and excluding grazing, usually at the end of the rainy season (Shio et al., 2011), so that forage accumulation occurs in order to be grazed during the dry period and minimizes the negative effects of seasonal forage production on animal productivity (Santos et al., 2014). The forage accumulation to be obtained during the pasture deferment period results from two processes: growth and development (including senescence) (Silva et al., 2019a). Changes in pasture structure occur during the deferment period and are also characterized by low nutritional value as a consequence of changes in environmental conditions and of the forage plant phenology itself, which tend to reduce the performance of ruminants (Euclides et al., 2019).

Supplementation emerges as a simple strategy to improve sheep productivity in systems that adopt deferred pastures as the basic diet (Fernandes et al., 2017; Gurgel et al., 2020). Supplementation is used for both an attempt to address the nutritional deficiencies of the pasture by providing the balance of the animals' diet, and also to reduce the risk caused by fluctuating pasture dry matter production (Geron et al., 2012). Lamb growth speed is very important for producing sheep meat; the earlier and less costly the slaughter requirements, the more positive the results for the production system (Castro et al., 2012; Silva et al., 2019b; Ítavo et al., 2019).
Soybean meal is the most used protein concentrate in animal production systems, but its high cost restricts its use in regions which are far from its producers, which justifies the constant search for alternative foods to the use of soybean meal. Among the industrial residues available and with potential to be used in animal feed are cotton and babassu cakes (Abdalla et al., 2008; Gurgel et al., 2020), and coconut cakes, but little information is available on these sources for supplementing grazing animals. In this context, the objective of this study was to evaluate the effect of different protein sources on the performance of lambing ewes and their lambs in deferred Marandu grass pasture.

\section{MATERIALS AND METHODS}

The trial was performed in accordance with the rules of the Ethics Committee on Animal Use CEUA/UFRN (protocol 055/2016). The experiment was conducted in an area of the Study Group of Forage Agriculture (Grupo de Estudos em Forragicultura - GEFOR), Federal University of Rio Grande do Norte, Macaíba Campus-RN. The experimental period was from $09 / 20 / 2016$ to $03 / 23 / 2017$. The climate of the region is characterized as dry sub-humid with water surplus from May to August (Thorthwaite, 1948). The temperature data were obtained from the INMET database and the precipitation data (Figure 1) by a Ville de Paris stainless steel rain gauge installed at the experiment site.

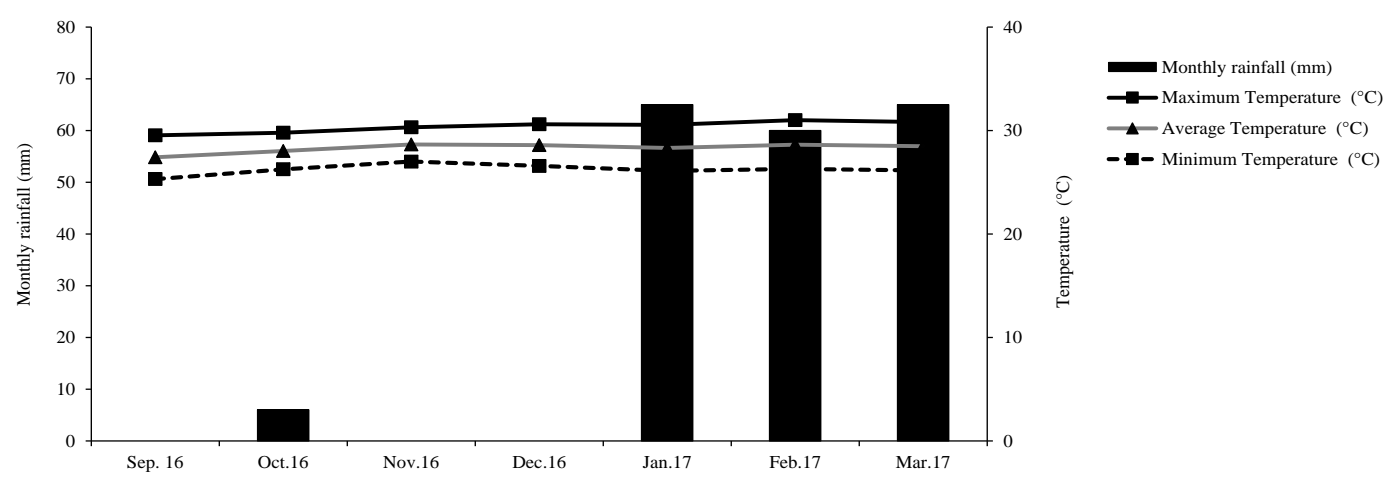

Figure 1. Monthly rainfall and average temperature during the period from September 2016 to March 2017.

The total pasture area was 5.1 hectares, composed exclusively of Brachiaria brizantha cv. Marandu. The pasture was fenced for 110 days and used from September of the same year until March 2017 (180 days). The employed grazing method was continuous stocking with a variable stocking rate. The evaluated treatments were four protein supplements: soybean meal, cotton cake, babassu cake and coconut cake. The structural variables of the deferred pasture were evaluated every 28 days 
during the whole usage period. Pasture height was measured with a graduated ruler in centimeters, with 100 readings performed per picket at the average curvature height of the leaves. Forage mass was estimated by cutting close to the forage soil contained within 21 representative areas using $1 \mathrm{~m}^{2}$ cutting frames. The samples were conditioned in paper bags, weighed (fresh weight) and dried in a forced air ventilation oven at $55^{\circ} \mathrm{C}$ until constant weight, then weighed again to determine the dry matter in the air and later corrected for the dry matter in oven at $105^{\circ} \mathrm{C}$ to obtain the forage dry mass $(\mathrm{kg} / \mathrm{ha} \mathrm{DM})$.

In evaluating the morphological components of the forage, seven subsamples were taken from the samples collected for determining the forage mass and manually separated into leaf blade, stem (stem + sheath) and dead material fractions, then dried in a forced ventilation oven at $55^{\circ} \mathrm{C}$ for 72 hours; next, the samples were ground and analyzed for determining crude protein $(\mathrm{CP})$, neutral detergent fiber (NDF), acid detergent fiber (ADF), in vitro digestibility of organic matter (IVDOM) and lignin (LIG) by Near-Infrared Reflectance Spectrophotometry (NIRS).

Sixty (60) Santa Inez lambing ewes aged between two and four years with an initial mean weight of $44.9 \pm 4.04 \mathrm{~kg}$ were used, with confirmed pregnancies from the third month of gestation. The animals were kept in a marandu grass pasture under continuous stocking during the day (7 a.m. to 4 p.m.) and housed in sheds in collective stalls during the night where they received a protein/energy concentrate supplement fixed at $0.5 \%$ of their body weight, calculated for category requirement (Nutrient..., 2007). The concentrates were adjusted to be isonitrogenated and urea was used to adjust the protein content (Table 1).

Table 1. Chemical composition and the supplementation percentage for the ewes in the final third of gestation until weaning and lambs in the growth phase

\begin{tabular}{lccccc}
\multicolumn{1}{c}{ Variable $\left(\mathrm{gkg}^{-1}\right)$} & \multicolumn{5}{c}{ Ingredients } \\
\cline { 2 - 6 } & Soybean & Babassu & Coconut & Cotton & Corn \\
\hline Dry mater & 837.5 & 897.8 & 872.8 & 844.6 & 840.9 \\
Mineral matter & 63.1 & 48.9 & 35.0 & 45.1 & 8.5 \\
Organic matter & 936.9 & 951.1 & 965.0 & 954.9 & 991.5 \\
Crude protein & 477.8 & 168.9 & 160.2 & 286.4 & 74.3 \\
Ether extract & 25.5 & 71.7 & 275.1 & 45.5 & 50.5 \\
Neutral detergent fiber & 169.5 & 515.8 & 447.2 & 413.1 & 65.0 \\
Acid detergent fiber & 93.7 & 311.8 & 301.0 & 266.7 & 37.7 \\
Lignin & 4.3 & 92.4 & 97.0 & 83.7 & 7.1 \\
Non-fibrous carbohydrate & 264.1 & 194.7 & 82.5 & 209.9 & 801.7 \\
Total carbohydrate & 433.6 & 710.5 & 529.7 & 623.0 & 866.7 \\
Total digestible nutrients & 791.1 & 602.0 & 921.2 & 654.6 & 902.8 \\
Digestible energy & 3.5 & 2.7 & 4.1 & 2.9 & 4.0 \\
& Concentrate composition & percentage for the lambs and ewes & \\
Concentrate of the lambs $(\%)$ & Ground corn & Protein source* & S. Mineral & Urea & Soybean oil \\
Concentrate with soybean $(\%)$ & 86.0 & $29.5 * *$ & 3.0 & - & 1.5 \\
Concentrate with cotton $(\%)$ & 72.5 & 14.6 & 1.2 & 3.7 & - \\
Concentrate with Babassu (\%) & 70.9 & 22.1 & 1.2 & 4.2 & - \\
Concentrate with coconut $(\%)$ & 68.3 & 22.9 & 1.2 & 5.0 & - \\
\hline
\end{tabular}

* protein source according to the treatment (soybean, cotton, babassu and coconut). ** soybean meal.

The ewes were weighed weekly to monitor performance in the gestation, parturition and weaning phases, and to adjust the amount of supplied concentrate. The body condition score (BCS) was measured every fifteen days according to the methodology described by Russel et al. (1969) during gestation (September to November 2016), parturition (December 2016) and weaning
(January to March 2016) periods. The total weight gain (TWG) was calculated by the difference between the initial weight and the final weight.

After birth, the ewes and their lambs were kept in a maternity picket stall for seven days. After this period the lambs were kept in pastures separated from the mothers during the day (from 7 to 16 
hours) and managed by the controlled feeding system. The lambs were supplemented with concentrate (Table 1) formulated to meet the requirements of growing lambs (Nutrient..., 2007) with ad libitum consumption, with leftovers maintained at around $10 \%$. Weaning was performed at 90 days of age.

To evaluate the performance of lambs, all animals were evaluated at birth and then every 7 days until weaning. The analyzed variables were birth weight and weaning weight $(\mathrm{kg})$, mean daily weight gain (DWG, g/animal/day) and total weight gain (TWG, g/animal/day). The total weight gain was obtained by the difference between the weaning weight and the birth weight.

A completely randomized design with four treatments and 15 replicates was adopted. The data regarding the structural characteristics of the pastures during the experiment were submitted to analysis of variance. The months corresponding to each physiological period of the ewes was considered as a fixed effect. The data regarding the ewes were submitted to analysis of variance and the different protein sources were considered as fixed effect. The data referring to the lambs and the fixed effect that composed the model were the different protein sources used as diets of the ewes, while the type of delivery was considered a random effect, as well as their interactions. When the variation source effects were significant by the F-test, they were analyzed by the Tukey test at 5\% significance.

\section{RESULTS AND DISCUSSION}

The interaction between the variation sources were not significant $(\mathrm{P}>0.05)$ for any of the evaluated variables. There were changes in the structural characteristics of deferred pasture during the usage period (Table 2), grass height and forage mass were higher when the ewes were in the gestation and weaning phases. These phases corresponded to the initial and final months of the experiment.

Table 2. Means of the structural variables of deferred Marandu grass during the usage period

\begin{tabular}{lccccc}
\hline \multicolumn{1}{c}{ Variables } & \multicolumn{3}{c}{ Periods } & \multirow{2}{*}{ SEM } & \multirow{2}{*}{ P-value } \\
\cline { 2 - 4 } & Gestation & Parturition & Weaning & & \\
\hline Height & $68.7^{\mathrm{a}}$ & $51.6^{\mathrm{b}}$ & $64.1^{\mathrm{a}}$ & 80.64 & 0.0464 \\
Forage mass $\left(\mathrm{kg} \mathrm{ha}^{-1} \mathrm{DM}\right)$ & $6650.2^{\mathrm{a}}$ & $5476.04^{\mathrm{b}}$ & $6337.3^{\mathrm{a}}$ & 284.89 & 0.0480 \\
Leaf blade mass (kg ha-1 DM) & 609.0 & 209.1 & 778.2 & 166.37 & 0.1318 \\
Stem mass $\left(\mathrm{kg} \mathrm{ha}^{-1} \mathrm{DM}\right)$ & $1525.6^{\mathrm{a}}$ & $664.5^{\mathrm{b}}$ & $880.3^{\mathrm{b}}$ & 164.00 & 0.0048 \\
Dead material mass $\left(\mathrm{kg} \mathrm{ha}^{-1} \mathrm{DM}\right)$ & 4515.6 & 4602.4 & 4678.8 & 369.80 & 0.9225 \\
Living:dead ratio & 0.5 & 0.2 & 0.3 & 0.09 & 0.1352 \\
\hline
\end{tabular}

Means followed by distinct letters on the line differ from one another by the Tukey test $(\mathrm{P}<0.05)$, SEM: Standard error of the mean.

The 110-day seeding period provided stem elongation and forage accumulation, being common in pastures under a longer deferment period. After the beginning of the pasture usage period, a decrease in height and forage mass was observed until the beginning of the rainy season; a fact that can be explained by the forage consumption by the animals and low forage accumulation, while the highest rainfall indexes in January, February and March (Figure 1) explain the recovery of grass height and forage mass during the weaning phase. According to Emerenciano Neto et al. (2017) there is a high relation between canopy height and forage mass.

The leaf mass was not altered during the deferent pasture use with a mean value of $566.1 \mathrm{~kg} \mathrm{ha}^{-1}$ DM. Pastures with long deferment periods are characterized by high forage mass and a small percentage of green leafy leaves, which results in little mass of this component. Santos et al. (2010) did not observe alteration in leaf mass in pastures with different deferment periods. The highest stem mass was observed in the months that comprised the ewes' gestation phases, with higher values for height also occurring in that period resulting in greater competition for light between the tillers. In this condition, the plant prioritizes carbon allocation in the internode elongation to position the new leaf area in the less shaded layers of the canopy (Sousa et al., 2019) which resulted in an increase in stem mass.

The dead material mass was not altered during the deferred pasture usage, with a mean of $4598.9 \mathrm{~kg}$ $\mathrm{ha}^{-1} \mathrm{DM}$. The greater competition for light results 
in shading the lower leaves and the death of smaller tillers (Difante et al., 2011) which increases the senescence and the participation of dead material in the deferred forage. The dead material can reduce forage capture and affect the voluntary consumption of grazing animals (Difante et al., 2010), but dead material in the deferred grazing condition represents an important source of fiber required by the animal, since forage accumulation in the dry period is practically null, and therefore supplementation use is important for utilizing the latent energy contained in the senescent fraction of the pasture. The living:dead ratio was not altered due to the deferred pasture use period, the increase in stem mass in the period that comprised the gestation phase was not enough to change the live:dead ratio due to the high dead material mass.

There were changes in the nutritive leaf blade value of the deferred pasture during its use (Table 3 ). The highest crude protein levels were observed during the parturition and weaning phases. The NDF was not changed according to the period of deferred pasture use. The NDF levels were considered high even in the months when the highest rainfall was recorded; a fact that can affect animal performance since levels above 55 to $60 \%$ negatively influence the voluntary intake of forage (Van Soest, 1965), which reinforces the idea that animals must be supplemented when adopting deferred pasture to optimize forage utilization.

Table 3. Nutritional value means of the morphological components of deferred Marandu grass during the usage period

\begin{tabular}{|c|c|c|c|c|c|}
\hline \multirow{2}{*}{ Variables $(\%)$} & \multicolumn{3}{|c|}{ Periods } & \multirow{2}{*}{ SEM } & \multirow{2}{*}{ P-Value } \\
\hline & Gestation & Parturition & Weaning & & \\
\hline \multicolumn{6}{|c|}{------------------- Leaf blade ----------------- } \\
\hline Crude protein & $6.4^{\mathrm{b}}$ & $8.3^{\mathrm{a}}$ & $8.1^{\mathrm{a}}$ & 0.32 & 0.0008 \\
\hline Neutral detergent fiber & 74.8 & 74.8 & 74.6 & 1.07 & 0.3295 \\
\hline Acid detergent fiber & $36.5^{\mathrm{a}}$ & $34.2^{\mathrm{ab}}$ & $33.1^{\mathrm{b}}$ & 0.70 & 0.0115 \\
\hline Lignin & $3.2^{\mathrm{a}}$ & $2.6^{\mathrm{b}}$ & $2.6^{\mathrm{b}}$ & 0.16 & 0.0179 \\
\hline In vitro digestibility of $\mathrm{OM}$ & $56.3^{\mathrm{b}}$ & $56.9^{\mathrm{b}}$ & $66.3^{\mathrm{a}}$ & 1.44 & 0.0029 \\
\hline \multicolumn{6}{|c|}{ 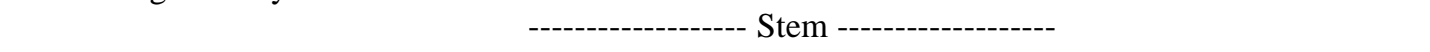 } \\
\hline Crude protein & 2.4 & 2.2 & 2.6 & 0.75 & 0.3371 \\
\hline Neutral detergent fiber & $85.1^{\mathrm{a}}$ & $85.5^{\mathrm{a}}$ & $81.8^{b}$ & 0.44 & 0.0001 \\
\hline Acid detergent fiber & $49.8^{a}$ & $48.0^{\mathrm{a}}$ & $44.9^{\mathrm{b}}$ & 0.53 & 0.0001 \\
\hline Lignin & $6.2^{\mathrm{a}}$ & $5.8^{\mathrm{a}}$ & $4.8^{\mathrm{b}}$ & 0.16 & 0.0001 \\
\hline In vitro digestibility of $\mathrm{OM}$ & $30.3^{b}$ & $33.1^{\mathrm{b}}$ & $38.1^{\mathrm{a}}$ & 1.02 & 0.0001 \\
\hline
\end{tabular}

OM: organic matter; SEM: Standard error of the mean; Averages followed by distinct letters in the line differ from one another by the Tukey test $(\mathrm{P}<0.05)$.

The ADF and LIG levels were higher during the gestation phase and lower in the weaning phase, which caused contrary behavior in IVDOM. These results can be explained by the higher rainfall observed in the period corresponding to the weaning phase (Figure 1), which concentrated more than $95 \%$ of the precipitation during the whole experimental period. Machado et al. (2008) emphasized water availability in the soil as a determining factor in the chemical composition of the leaf due to the plant accelerating the process of new tissue emergence, with these being of better nutritive value and greater digestibility.

The stem $\mathrm{CP}$ content was not modified during the usage period of the deferred pasture with an average value of $2.4 \%$. However, the structural fraction of the stem followed the trend of that observed in the leaf blades, with higher levels of NDF, ADF and LIG in the months corresponding to the gestation and parturition phases, with the highest IVDOM during weaning. The values characterize low nutritional quality in the deferred marandu grass stems, regardless of the evaluation month. During three years of evaluation in the dry period, Euclides et al. (2009) observed average CP contents of 8.7 and $5.0 \%$ and NDF of 5.0 and $3.7 \%$ higher than those in the Marandu grass leaf blades and stems. The best nutritional value found by these authors can probably be explained by the soil and climate conditions of the region (west central) and adopted grazing method (intermittent stocking). 
There was no effect of the evaluation months for crude protein, neutral detergent fiber, acid detergent fiber, lignin or in vitro digestibility of the organic matter of the dead material, with a mean of $2.4 \%, 83.8 \%, 47.6 \%, 5.5 \%, 34.1 \%$ of $\mathrm{DM}$, respectively. The low levels of $\mathrm{CP}$ and IVDOM and higher percentages of the structural fractions (NDF, ADF and LIG) are considered normal, because there is an increase in the support structures and cell wall thickening with large amount of lignin due to the advancing plant age, which causes a decrease in proportion of nonfibrous compounds which are more easily digested and utilized by the animal (Valente et al., 2010).

The body weight of the ewes during the gestation, parturition and weaning periods (Table 4) did not differ according to the protein sources. These results show the efficiency of the evaluated protein sources in meeting the needs of fetal development, without generating losses to the ewe, and also provide for their recovery at weaning, thus characterizing the viability of using alternative protein foods.

Table 4. Mean body weight (BW) in gestation, parturition and weaning, and total weight gain (TWG) of lambing ewes maintained in deferred Marandu grass pasture and supplemented with different protein sources

\begin{tabular}{lccccccc}
\hline \multicolumn{1}{c}{ Variables } & Soybean & Babassu & Coconut & Cotton & Mean & SEM & P-Value \\
\hline BW Gestation (kg) & 45.9 & 43.9 & 46.2 & 43.1 & 45.0 & 0.62 & 0.8901 \\
BW Parturition (kg) & 41.8 & 40.2 & 40.4 & 36.8 & 39.9 & 0.70 & 0.5310 \\
BW Weaning (kg) & 37.5 & 35.9 & 37.7 & 34.5 & 36.6 & 0.78 & 0.6845 \\
TWG (kg) & -6.0 & -5.5 & -6.0 & -7.0 & -6.0 & 1.41 & 0.9115 \\
\hline
\end{tabular}

Means followed by different letters in the line differ by the Tukey's test $(\mathrm{P}<0.05)$. SEM: Standard error of the mean.

Associating deferred pasture with supplementation guarantees a bulking source during the dry season to the animals, being necessary to maintain adequate ruminal functioning and a high supply of metabolizable energy, which together with satisfactory amounts of degradable protein in the rumen increases microbial protein synthesis (Detmann et al., 2011).

The weight gains of the ewes did not differ between the protein sources and was negative. This fact is due to the sum of the sheep weight with the fetus (s) weight and the attachments and fetal fluids during pregnancy (beginning of the experiment), and of course the ewes were empty at the end of the experiment. Moreover, the requirements increased in the final third of gestation, where 70 to $85 \%$ of the fetal development occurs (Silva et al., 2015). In addition, the nutritive value of the pasture had its most critical values and the supplementation level was not changed (Tables 2 and 3).

Body condition score (BCS) in the gestation, parturition and weaning stages for the ewes receiving soybean meal remained above 3 (Figure 2 ), while $50 \%$ of the ewes that received cotton cakes had scores between 2.5 and 3 . The ewes that consumed babassu cake as a protein source were maintained with scores ranging from 2.5 to 3.5. The tendency observed was repeated by those that consumed coconut cake, but in the weaning phase the ewes were below 3 .
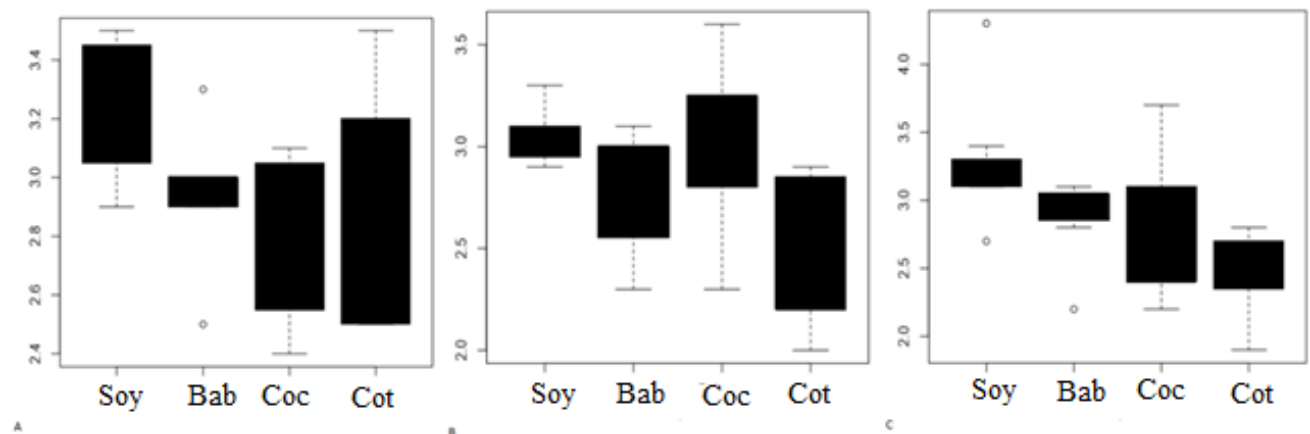

Figure 2. Body condition score of ewes fed with different protein sources in deferred Marandu grass pasture in the: (A) gestation; (B) parturition; and (C) weaning stages. 
When evaluating different levels of coconut cake inclusion in the diets of sheep Bosa et al. 2012 observed that the animals rejected the ration from $50 \%$ inclusion of coconut cake and selected their food, which demonstrates some reducing effect of coconut cake acceptance by the animals. This effect was associated with the high fat content of the cake (19.05\%). This rejection was also observed in this work, where the coconut presented 27\% EE (Table 1), which justifies the effect on the BCS of the ewes receiving the coconut cake.

The ewes that consumed coconut ended up with a low BCS at the end of the breastfeeding period. Ribeiro et al., 2003 observed that as BCS increases, there was an increasing percentage of pregnant ewes, as ewes with BCS of 3.0 and 4.0 presented $92 \%$ and $98 \%$ pregnancy, respectively. Supplementation associated with a high supply of forage (Table 2), even of low quality, is able to keep the ewes at consistent weights and BCS with their physiological phase, because (with supplementation usage) there is an increase in the amount of substrate for fermentation and consequent increase in the amount of microbial protein produced (Assad et al., 2015).

There was no interaction between the protein sources and the type of delivery for any of the analyzed variables. The lambs' birth weight was affected by protein sources (Table 5), where the highest values were observed in the lambs of ewes who received soybean meal and babassu cake when compared to those of the ewes supplemented with coconut cake.

Table 5. Performance of lambing ewes supplemented with different protein sources in deferred Marandu grass pasture

\begin{tabular}{lcccccc}
\hline Variables & Soybean & Babassu & Coconut & Cotton & SEM & P-Value \\
\hline Birthweight (kg) & $3.49^{\mathrm{a}}$ & $3.44^{\mathrm{a}}$ & $2.82^{\mathrm{b}}$ & $3.19^{\mathrm{ab}}$ & 0.01 & 0.0291 \\
Weaning weight (kg) & $19.55^{\mathrm{a}}$ & $17.29^{\mathrm{a}}$ & $15.63^{\mathrm{b}}$ & $17.29^{\mathrm{ab}}$ & 0.07 & 0.0194 \\
DWG (kg/day/animal) & $0.178^{\mathrm{a}}$ & $0.176^{\mathrm{ab}}$ & $0.142^{\mathrm{b}}$ & $0.156^{\mathrm{ab}}$ & 0.01 & 0.0351 \\
TWG (kg) & $16.06^{\mathrm{a}}$ & $14.11^{\mathrm{ab}}$ & $12.80^{\mathrm{b}}$ & $15.84^{\mathrm{ab}}$ & 0.06 & 0.0339 \\
\hline
\end{tabular}

DWG - Daily weight gain; TWG - Total weight gain. SEM: Standard error of the mean. Means followed by distinct letters in the line differ between them by the Tukey's test $(\mathrm{P}<0.05)$.

Fatty acidification may have occurred due to the presence of saturated and unsaturated fatty acids in the coconut cake, with lauric acid being the main fatty acid present, comprising about $45 \%$ of the total fatty acids content (Zambiazi et al., 2007). In addition, the presence of coconut endocarp contributed to the decrease in food digestibility, compromising maternal performance and consequently reducing birth weight and weaning weight.

The ewes that received the babassu cake birthed lambs with similar weight to those from the soybean; this fact contradicts the result obtained by (Xenofonte et al., 2008) where they found that the response to low weight may have been associated to the reduced intake of metabolizable energy. The response observed in the birth weight was repeated for the weight at weaning, as the ewes that received soybean and babassu as protein sources weaned heavier lambs. This result is a reflection of the greater average daily gain and total of these animals, where it is possible to infer that the ewe's diet is determinant for the performance of the lambs in the initial phase, and that the management, however correct it is, does not repair the errors committed during pregnancy. Furthermore, heavier weaned lambs will be finished faster.

There was an effect of the type of delivery for all analyzed variables, wherein lambs born from single delivery recorded the highest weights at birth and weaning, in addition to having a higher average daily gain (Table 6). This may be explained due to the partition of the nutrients and the little intrauterine space when two fetuses develop. After birth, the milk consumption by lambs from single deliveries is higher than double deliveries. (Rocha et al., 2009) also observed influences of the type of delivery on the lambs' performance from birth to weaning, in which the single lambs presented a higher average daily gain than twin lambs. 
Table 6. Performance of lambs from different types of birth from ewes supplemented with different protein sources in deferred Marandu grass pastures

\begin{tabular}{lcccc}
\hline Variables & Single & Twins & SEM & P-Value \\
\hline Birthweight (kg) & 3,4 & 2,9 & 0,01 & 0,0034 \\
Weaning weight (kg) & 19,0 & 15,8 & 0,07 & 0,0021 \\
DWG (kg/day/animal) & 0,173 & 0,143 & 0,01 & 0,0043 \\
TWG (kg) & 15,6 & 12,9 & 0,06 & 0,0041 \\
\hline
\end{tabular}

DWG - Daily weight gain; TWG - Total weight gain. SEM: Standard error of the mean. Means followed by distinct letters in the line differ between them by the Tukey's test $(\mathrm{P}<0.05)$.

The benefits of twin birth are increased productivity, shorter generations, and increased herd production rate. Single lambs obtained greater weight gain, but it is more advantageous to wean two animals for greater meat production. The main problems with the twin lambs are the low birth weight and the fragility of these animals that will have difficulty feeding, and they can also suffer competition with more developed lambs, with a differentiated management being recommended with respect to the nutrition of animals from twin births (Castro et al., 2012).

It should be noted that regardless of the protein source used in the ewes' supplementation or the type of birth, the observed variation is consistent with the expected performance of the animals in this period, since the average daily gain of the animals was $0.163 \mathrm{~kg} / \mathrm{lamb} /$ day, and is between 0.120 and $0.200 \mathrm{~kg} / \mathrm{lamb} /$ day (Nutrient..., 2007). This was possible by adequately combining pasture management and food supplementation alternatives, since modern breeding systems with adopted management and feeding practices enable better performance of the animals, and consequently better economic return.

\section{CONCLUSIONS}

The use of deferred pasture enables a high forage supply in the dry season of the year, even if it is of low quality; and when combined with minimum supplementation levels $(0.5 \%)$, it is possible to keep the ewes at a body condition score and weight that is consistent with the physiological phase, as well as allowing to wean lambs within the standard recommended by the market. Babassu, coconut and cotton cakes can replace soybean meal in supplementing lambing ewes maintained in deferred Marandu grass pasture without damaging their performance, but only the babassu and cotton cakes enabled an even performance by the lambs to soybean meal.

\section{ACKNOWLEDGEMENTS}

This research was funded by the Coordination for the Improvement of Higher Education Personnel Brazil (CAPES) - Financing Code 001 and the National Council for Scientific and Technological Development (CNPq) and supported by the Federal University of Rio Grande do Norte e Federal University of Mato Grosso do Sul.

\section{REFERENCES}

ABDALLA, A.L.; SILVA FILHO, J.C.; GODOI A. R.; CARMO, C.A. et al. Utilização de subprodutos da indústria de biodiesel na alimentação de ruminantes. Rev. Bras. Zootec., v.37, p.260-258, 2008.

ASSAD, L.V.F.; ZERVOUDAKIS, J.T.; CABRAL, L.S.; HATAMOTOZERVOUDAKIS, L.K. et al. Degradable protein in rumen and frequency of supplementation for it recreates of bovine in pasture. Semin. Cienc Agrar., v.36, p.2119-2130, 2015.

BOSA, R.; FATURI, C.; VASCONCELOS, H.G.R.; CARDOSO A.M. et al. Consumo e digestibilidade aparente de dietas com diferentes níveis de inclusão de torta de coco para alimentação de ovinos. Acta. Sci. Animal. Sci., v.34, p.57-62, 2012.

CASTRO, F.A.B.; RIBEIRO, E.L.A.; KORITIAKI, N.A.; MIZUBUTI, I.Y. et al. Desempenho de cordeiros Santa Inês do nascimento ao desmame filhos de ovelhas alimentadas com diferentes níveis de energia. Semin. Cienc. Agrar., v.33, p.3379-3388, 2012.

DETMANN, E.; QUEIROZ, A.C.; ZORZI, K.; MANTOVANI, H.C. et al. Degradação in vitro da fibra em detergente neutro de forragem tropical de baixa qualidade em função da suplementação com proteína verdadeira e/ou nitrogênio não-proteico. Rev. Bras. Zootec., v.40, p.1272-1279. 2011. 
DIFANTE, G.S.; EUCLIDES, V.P.B.; NASCIMENTO JÚNIOR, D.; SILVA, S.C. et al. Desempenho e conversão alimentar de novilhos de corte em capim-tanzânia submetido a duas intensidades de pastejo sob lotação rotativa. Rev. Bras. Zootec., v.39, p.33-41, 2010.

DIFANTE, G.S.; NASCIMENTO JÚNIOR, D.; SILVA, S.C.; EUCLIDES, V.P.B. et al. Características morfogênicas e estruturais do capim-marandu submetido a combinações de alturas e intervalos de corte. Rev. Bras. Zootec., v.40, p.955-963, 2011.

EMERENCIANO NETO, J.V.; DIFANTE, G.S.; LANA, A.M.Q.; CAMPOS, N.R.F. et al. Sward structure and herbage accumulation of massai guineagrass pastures managed according to pregrazing heights, in the northeast of Brazil. $J$. Agric. Sci., v.9, p.155-163, 2017.

EUCLIDES, V.P.B.; MACEDO, M.C.M.; VALLE, C.B.; DIFANTE, G.S. et al. Valor nutritivo da forragem e produção animal em pastagens de Brachiaria brizantha. Pesqui. Agrar. Bras., v.44, p.98-106, 2009.

EUCLIDES, V.P.B.; MONTAGNER, D.B.; MACEDO, M.C.M.; ARAÚJO, A.R. et al. Grazing intensity affects forage accumulation and persistence of Marandu palisadegrass in the Brazilian savannah. Grass Forage Sci., v.74, p.450-462, 2019.

FERNANDES, L.S.; DIFANTE, G.S.; MONTAGNER, D.B.; EMERENCIANO NETO, J.V. et al. Structure of massai grass pasture grazed on by sheep supplemented in the dry season. Grassl. Sci., v.63, p.177-183, 2017.

GERON, L.J.V.; MEXIA, A.A.; GARCIA J.; SILVA, MM. et al. Suplementação concentrada para cordeiros terminados a pasto sobre custo de produção no período da seca. Semin. Cienc. Agrar., v.33, p.797-808, 2012.

GURGEL, A.L.C.; DIFANTE, G.S.; EMERENCIANO NETO, J.V.; ROBERTO, F.F.S et al. Impact of supplementation with different protein sources on the parasitological profile of ovine matrices and development of lambs. Biosci. J., v.36, p.496-506, 2020
ÍTAVO, C.C.B.F.; ÍTAVO, L.C.V.; ESTEVES, C.A.T.; SAPATERRO, G.A. et al. Influence of solid residue from alcoholic extraction of brown propolis on intake, digestibility, performance, carcass and meat characteristics of lambs in feedlot. J. Anim. Feed Sci., v.28, p.149-158, 2019.

MACHADO, L.A.Z.; FABRÍCIO, A.C.; GOMES, A.; ASSIS, P.G.G. et al. Desempenho de animais alimentados com lâminas foliares, em pastagem de capim-marandu. Pesqui. Agrar. Bras., v.43, p.1609-1616, 2008.

NUTRIENT requeriments of small ruminants: sheep, goats, cervids. 2.ed.Washington: National Academy Press, 2007.

RIBEIRO, L.A.O.; FONTANA, C.L.; WALD, V.B.; GREGORY, R.M. et al. Relação entre a condição corporal e a idade das ovelhas no encarneiramento com a prenhez. Cienc. Rural, v.33, p.357-361, 2003.

ROCHA, L.P.; FRAGA, A.B.; ARAÚJO FILHO, J.T.; FIGUEIRA RF. et al. Desempenho de cordeiros cruzados em Alagoas, Brasil. Arch. Zootec., v.58, p.145-148, 2009.

RUSSEL, A.J.F.; DONEY, J.M.; GUNN, R.G. Subjective assessment of body fat in live sheep. $J$. Agric., Sci., v.72, p.451-454, 1969.

SANTOS, M.E.R.; CASTRO, M.R.S.A.; GOUVÊIA, S.C.; GOMES, V.M. et al. Contribuição de perfilhos aéreos e basais na dinâmica de produção de forragem do capimbraquiária após o pastejo diferido. Biosci. J., v.30, p.424-430, 2014.

SANTOS, M.E.R.; FONSECA, D.M.; GOMES, $\mathrm{V}$; BALBINO E. et al. Estrutura do capimbraquiária durante o diferimento da pastagem. Acta. Sci. Anim. Sci., v.32, p.139-145. 2010.

SHIO, A.R.; VELOSO, C.M.; SILVA, F.F.; İTAVO, L.C.V. et al. Ofertas de forragem para novilhas nelore suplementadas no período de seca e transição seca/águas. Acta. Sci. Anim. Sci., v.33, p.9-17, 2011.

SILVA, F.L.M.; POLIZEL, D.M.; FREIRE, A.P.A.; SUSIN, I. Manejo nutricional de ovelhas gestantes e lactantes com ênfase em carboidratos fibrosos e não fibrosos. Rev. Agropecu. Tec., v.36, p.1-8, 2015. 
SILVA J.A.; ÍTAVO, C.C.B.F.; ÍTAVO, L.C.V.; MORAIS, M.D. et al. Dietary addition of crude form or ethanol extract of brown propolis as nutritional additive on behaviour, productive performance and carcass traits of lambs in feedlot. J. Anim. Feed Sci., v.28, p.31-40, 2019a.

SILVA, P.H.F.; CARVALHO, C.A.B.; MALAFAIA, P.; GARCIA, F.Z. et al. Morphological and structural characteristics of Urochloa decumbens Stapf. deferred pasture grazed by heifers under two periods of proteinenergy supplementation. Acta. Sci. Anim. Sci., v.41, p.1807-8672, 2019b.

SOUSA, B.M.L.; RIZATO, C.A.; FAGUNDES, J.L.; FONTES, P.T.N. et al. Tillering dynamics of digit grass subject to different defoliation frequencies. Pesqui. Agrar. Bras., v.54, p.1-9, 2019.

THORTHWAITE, C.W. An approach toward a rational classification of climate. Geogr. Rev., v.38, p.55-93, 1948.
VALENTE, B.S.M.; CÂNDIDO, M.J.D.; CUTRIM JUNIOR, J.A.A.; PEREIRA, E.S. et al. Composição químicobromatológica, digestibilidade e degradação in situ da dieta de ovinos em capim-tanzânia sob três frequências de desfolhação. Rev. Bras. Zootec., v.39, p.113-120, 2010.

VAN SOEST, P.J. Voluntary intake relation to chemical composition and digestibility. J. Anim. Sci., v.24, p.834-844, 1965.

XENOFONTE, A.R.B.; CARVALHO, F.F.R.; BATISTA, A.M.V.; ANDRADE, R.P.X. et al. Desempenho e digestibilidade de nutrientes em ovinos alimentados com rações contendo farelo de babaçu. Rev. Bras. Zootec., v.37, p.2063-2068, 2008.

ZAMBIAZI, R.C.; PRZYBYLSKI, R.; ZAMBIAZI, M.W.; MENDONÇA, C.B. Fatty acid composition of vegetable oils and fats. B.CEPPA., v.25, p.111-120, 2007. 